\title{
Cognitive Dimensions in Community Response to the Free Vaccination Programs in Suppressing theSpread of Covid- 19 in Sidoarjo Regency
}

\author{
*Trenda Aktiva Oktariyanda ${ }^{1}$, Meirinawati ${ }^{2}$, Eva Hany Fanida ${ }^{3}$, Fitrotun Niswah $^{4}$, Ngukup \\ Cahyo Achmadja ${ }^{5}$
}

${ }_{1,2,3,4,5}$ Department of Public Administration, Universitas Negeri Surabaya

* Email: trendaoktariyanda@unesa.ac.id

\begin{abstract}
Based on data on the positive cases of the Indonesian Covid-19 pandemic in the period March 2020 to March 2021, there were 1,290,790 people. Meanwhile, the distribution of positive cases in Sidoarjo Regency until March 2021 is 10,787 people. In order to suppress the increase in new positive cases and achieve communal immunity, the Indonesian government issued Presidential Regulation Number 99 of 2020 concerning Vaccine Procurement and Vaccination Implementation in the context of Combating the 2019 Corona Virus Disease (COVID-19) Pandemic (State Gazette of the Republic of Indonesia Year 2020 Number227). Diplomacy is taking through the Minister of Foreign Affairs in order to secure the stock of vaccines available for the people of Indonesia. Through this policy, the government managed to secure 270 million doses of various brands of vaccines. Vaccine distribution will be carried out in several stages and will be distributed to district or city governments to be forward to health facilities in their area. Therefore, researchers are interested in taking the research title "Cognitive Dimensions in Community Response to the Free Vaccination Programs in Suppressing the Spread of COVID-19 in Sidoarjo Regency". This research is quantitative research using independent variables. They described based on data sourced from questionnaires. The research location is in the Sidoarjo Regency and has a population of 2,262,440 million people with a total sample of 100 incidental people.
\end{abstract}

Keywords: Covid-19 Pandemic, Community Response, Cognitive Dimensions, Free Vaccination Programs.

\section{INTRODUCTION}

The COVID-19 pandemic that began to enter Indonesia in the first quarter of 2020 showed a trend of increasing severe cases. It was recorded that in March 2021, there were 129.844 positive people, 1.290 cases were declared cured, 790 people died, and 39.550 people died (Ministry of Health of the Republic of Indonesia, 2021). The highest record for adding daily positive COVID-19 cases was recorded at 54.000 on July 14, 2021 (CNBC Indonesia, 2021) [1].

The Indonesian government has made various efforts to end the pandemic in Indonesia. Some of them are PSBB (Large-Scale Social Restrictions, Transitional PSBB, Strict PSBB, PPKM (Enforcement of Restrictions on Community Activities), Micro PPKM, PPKM Level 4, PPKM Level 3, and PPKM Level 1-2. (Permatasari, 2021) [2]. The Government of Indonesia has also issued the Decree of the Minister of Health of the Republic of Indonesia Number
Hk.01.07/Menkes/382/2020 concerning Health Protocols for the Community in Public Places and Facilities in the context of Prevention and Control of Corona Virus Disease 2019 (COVID-19) [3]. People in activities are asked to do 5 meters ranges, which is a health protocol including washing hands, wearing masks, keeping a distance, staying away from crowds and reducing mobility.

National data in March 2021, Positive as many as 129.844 people, the number of cases declared cured as many as 1.290.790 people (Ministry of Health, 2021) [4]. The distribution from East Java Province is 138.7 positive 06 people, the number of cases declared cured 123.310 people, and the number of cases died was 9.530 people. (COVID-19 Task Force 2021). Particular distribution in Sidoarjo positive as much as 10.787 lives, recovered as much as 10.144 people, died as many as 606 lives and suspect as many as 5.994 people (Sidoarjo Regency Communication and Information Office, 2021) [5]. 
Figure 1 Graph Distribution Covid-19 Per day in East Java province

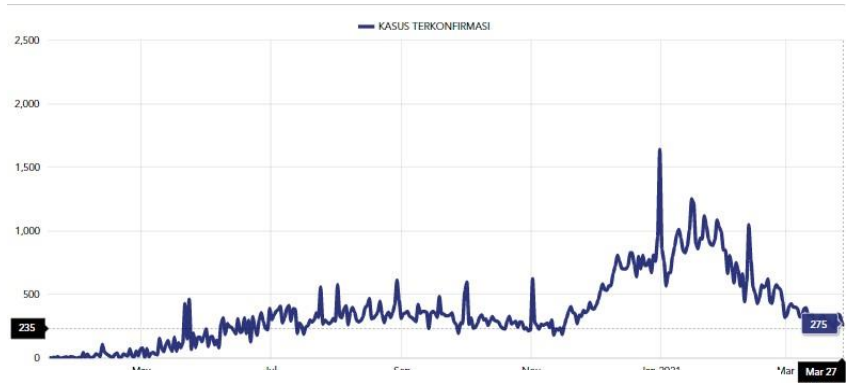

Source: https://covid19.go.id/peta-sebaran-covid19

Various efforts of the Indonesian Government's over yet enough to stop the spread of COVID-19. Herd immunity or communal immunity is indirect protection for vulnerable people by most people who are immune to infection. Communal immunity has also been shown to reduce cases through vaccines for infectious diseases such as measles, polio, rubella and diphtheria. Vaccine assistance is needed to accelerate the achievement of herd immunity, (Ramachandran, et al., 2020) [6].

The government of Indonesia tried to pressure the pandemic through Presidential Regulation Number 99 of 2020 concerning Vaccine Procurement and Vaccination Implementation in the context of Combating the Corona Virus Disease 2019 (COVID-19) Pandemic (State Gazette of the Republic of Indonesia Year 2020 Number 227) [7]. Based on the Presidential Decree, the government, through the foreign minister in 2020, will conduct international diplomacy to gain access to the Covid-19 vaccine and budgetary support for multilateral cooperation and other necessary support.

As a result of the above policy, Indonesia has secured a supply of 270 million vaccine doses from the target requirement of 426 vaccine doses. The vaccines consist of various brands, including Sinovac, Novavax, COVAX/GAVI, AstraZeneca and Pfizer/BioNTech. Vaccination is divided into four stages; the first stage (January-April 2021) prioritizes health workers, assistant health workers, support personnel, and students undergoing professional medical education who work at the Health Facilities. The second stage (January-April 2021) is divided into two target groups: public service officers, including the TNI, Polri, law enforcement officers, and other service officers. The next group is the elderly (> 60). The third phase (April 2021-March 2022) targets vulnerable communities from geospatial, social and economic aspects. Phase four (April 2021-March 2022) is given to other economic actors with a cluster approach in accordance with the availability of vaccines.
The government, through Regulation of the Minister of Health Number 84 of 2020 concerning the Implementation of Vaccination in the Context of Combating the Corona Virus Disease 2019 (COVID-19) pandemic, the distribution of vaccines is handed over to the district or city government for further distribution to health facilities in their area. Based on the description and problems above, the research is devoted to the study of vaccination response. The research location is focused on Sidoarjo Regency with the consideration of the Ministry of Health's letter that the priority of the first phase of the Sinovac vaccine is Surabaya, Gresik and Sidoarjo. (SurabayaBisnis.com) Therefore, researchers are interested in taking the research title "Cognitive Dimensions in Community Response to the Free Vaccination Programs in Suppressing the Spread of COVID-19 in Sidoarjo Regency ".

\section{METHODS}

\subsection{Type of Research}

This study uses a quantitative research approach with descriptive type. Sugiyono (2012) [8] states that quantitative research is research in which the kind of data is in the form of numbers or qualitative information that is numbered. The choice of the quantitative approach in this study was due to adjusting the research objectives, namely measuring and analyzing the results of the community's response to the free vaccination program in suppressing the spread of COVID-19 in Sidoarjo Regency.

Based on this, it can be seen that this study uses independent variables that will then be described based on data taken using questionnaires distributed online to respondents (community). So this study does not attempt to make comparisons or connect existing variables because it only describes independent variables.

\subsection{Research sites}

This research was carried out in the Sidoarjo Regency area, which consists of 18 sub-districts that have a relatively high level of COVID-19 spread based on data from the Indonesian Ministry of Health, the COVID-19 Task Force, and the Sidoarjo Regency Government, which are described in Chapter 1. Additional data shows that in Sidoarjo Regency, the COVID-19 vaccine is currently being administered.

\subsection{Population and Sample}

\subsubsection{Population}

The population of this research is the people of Sidoarjo Regency. Please note that Sidoarjo Regency consists of 18 sub- 
districts, 31 sub-districts, and 322 villages (out of a total of 666 sub-districts, 777 sub-districts, and 7,724 villages in East Java). The population in Sidoarjo Regency in 2019 results from population projections reaching $2,262,440$ with a composition of 1,140,627 male residents and 1,121,813 female residents. With an area of $634.38 \mathrm{~km}^{2}$ and population distribution of 2,880 people $/ \mathrm{km}^{2}$. The population taken in this study is the population of Sidoarjo Regency that is eligible for vaccination (productive age and elderly) of $\pm 1,533,000$ people.

\subsubsection{Sample}

The sample is a component of the population used to conclude or describe the population. Sample selection with the right method can be used to describe the actual population condition accurately. The sampling technique in this research is the incidental sampling technique. Random sampling is a sampling method or technique based on chance. Anyone who coincidentally or incidentally meets a researcher can be used as a sample if it is deemed that the person who happened to be completed is suitable as a data source. The samples taken in this study were from several communities scattered from several sub-districts in the Sidoarjo district. From this population, it can then be determined a certain number of samples developed by Slovin (Ariola et al., 2006) [9] the formula that will be used to measure samples from The population is known in number, as follows:

$$
n=\frac{N}{1+N(e)^{2}}
$$

$$
n=\frac{1.533 .000}{1+1.533 .000(0,1)^{2}}
$$

$$
n=\frac{1.533 .000}{1+1.533 .000 \times 0,01}
$$

$$
n=\frac{1.533 .000}{1.5331}
$$

$$
n=99,99 \text { rounded up to } 100
$$

\section{Information}

$n=$ Number of samples

$N=$ Total Population

$e=$ Error Tolerance Limit of $10 \%$

So in this study, researchers determined the number of samples of people incidentally eligible to receive the vaccine spread in Sidoarjo Regency as many as 100 people.

\subsection{Variables and Operational Definitions of Variables}

\subsubsection{Variables}

Understanding variables, according to Sugiyono (2012) [8] in his book, states that: "Variables are called variables because there are variations. For example, weight can be said to be variable because the importance of a group of people varies from one person to another. Likewise motivation, perception can also be said to be a variable because, for example, the perception of a specific group of people varies. So if the researcher chooses the research variables, both those owned by people, objects, as well as particular fields of activity and science, there must be variations. Variables that have no variation are not said to be variables. To be able to vary, the research must be based on a group of data sources or objects that vary.

As mentioned above, the research variable is the community's response to the COVID-19 free vaccination program. Because the nature of the community's response is a trait that has a very high variation, then the interpretation of the response shown by the community is the variable in the research conducted by the researcher.

\subsubsection{Operational Definition of Variables}

The operational definition is the variable formulation that is used as a guide in data collection. The operational definition in this study, researchers There are many factors that affect the results of a person's response. In general, one of the fundamental factors is the Cognitive Aspect.

From the cognitive aspect above, to find out the results of the response to public understanding of health protocols in the implementation of the Covid-19 free vaccination program, the research team used three indicators as described above.

\subsubsection{Research Instruments}

The research instrument is a media aid in conducting research to obtain the necessary data. In this study, the research team used a questionnaire format google form as a tool in collecting data in the field. According to Sugiyono (2012) [8], in principle, research is to take measurements, so there must be an excellent measuring instrument. Measurement tools in research are usually referred to as research instruments. In this case, the research instrument used refers to the Regulation of the Minister for Empowerment of State Apparatus and Bureaucratic Reform Number 14 of 2017 concerning Guidelines for Community Satisfaction Surveys on the Implementation of Public Services. 


\subsubsection{Data Collection Techniques The data}

Collection techniques of this research are adapted to the typical data, namely primary data and secondary data that can help the research team to draw conclusions, namely:

\subsubsection{Primary data}

Primary Daya is this data obtained directly at the location of the research object, where the primary data object is a questionnaire (questionnaire). The questionnaire is a data collection technique that is done by giving a set of questions or written statements to respondents to answer (Sugiyono, 2012). Considering that this research was conducted during the COVID-19 pandemic, the questionnaires distributed online to the public were compiled in a format, google form making it easier for the research team to collect data in the field.

\subsubsection{Secondary data.}

This data was obtained by the following techniques:

\subsection{Documentation}

Documentation is a data collection technique by collecting existing documents and obtained from previous activities. Documentation is a data collection technique that is not too difficult when compared to other data collection techniques.

\subsection{Literature study}

Literature study is a technique of collecting data obtained from literature or books, scientific works, journals (national/international), as well as continuous expert opinions with what is needed and used in research.

\subsubsection{Validity Test and Reliability Test}

Researcher was referring to the use of the online questionnaire (questionnaire) technique as the main instrument of research to find out how the results of the community's response to the free vaccination program in suppressing the spread of COVID-19 in Sidoarjo Regency, it is necessary to test validity and reliability tests to make the results of this study accurate.

\subsubsection{Data Analysis Techniques}

According to Sugiyono (2012), data analysis is an activity after data from all respondents, or other data sources are collected. Activities in data analysis include: classifying data based on variables and types of respondents, tabulating data based on variables from all respondents, presenting data for non-variables studied, performing calculations to answer the problem formulation, and performing calculations to test hypotheses that have been proposed. For research that does not formulate a hypothesis, the last step is not carried out.
In this study, the data analysis technique used is quantitative data analysis. This is in accordance with the purpose of this study, which is to describe the results of the cognitive dimensions in community response to the free vaccination programs in suppressing the spread of COVID-19 in Sidoarjo Regency based on the results of the questionnaire. In this quantitative data analysis, it is divided into three stages, namely data processing, data organization, and finding results. The explanation of the three stages is as follows:

\subsection{Data processing}

In this data processing stage, the initial step is the editing process. This editing process is carried out to check and correct the collected data related to whether or not the questionnaire was completed by respondents, the readability of the writing, the clarity of the meaning of the answers, the suitability, and consistency between the answers to one question and another.

The next stage is the process of coding. The process coding itself, according to Hasan (2002), is the stage of giving or creating codes for each data that belongs to the same category.

In this study, the data obtained from filling out the questionnaire by the respondents after being edited then the data will be included in the presentation of the data in the form of a frequency table which is intended to clarify in viewing the data categories. as for the categories of data from the questionnaire results are based on 3 (three) categories, namely:

a. A score of 1 (one) is given to the Bad answer

b. A score of 2 (two) is given to the answer Enough

c. A score of 3 (three) is given to the Good answer

\subsection{Data organization}

After the data processing stage, the next step is organizing the data. The activities carried out in managing the data include:

\subsection{Calculating Questionnaire Item Score}

After the results of the questionnaire have been entered in the frequency table that corresponds to the 3 (three) categories above, the next step is to perform calculations from each type, where the estimate is based on the respondent group using the following formula:

$$
\mathrm{P}=\frac{f}{N} \times 100 \%
$$

Information:

$\mathrm{P}=$ Percentage of respondents' answers

$\mathrm{f}=$ Number of respondents' answers 
$\mathrm{N}=$ Maximum score

\subsection{Creating Interval Class}

Interval class is helpful for determining the value level of the measured variable results. In this study, the value of the interval class is expressed in percentages. Interpretation criteria for interval class scores in this study are shown in the following table:

Table 1 Interpretation Criteria Score

\begin{tabular}{|c|c|l|}
\hline Class & Score Interpretation Criteria & Category \\
\hline 3 & $66,6 \%-100 \%$ & Good \\
\hline 2 & $33,4 \%-66,6 \%$ & Enough \\
\hline 1 & $0 \%-33,3 \%$ & Bad \\
\hline
\end{tabular}

Source: Research Results, 2021 (processed data)

\subsection{Calculating Respondents' Answer Score}

In calculating the answer scores from respondents, the formula used by researchers is as follows:

\section{$\frac{\text { Accumulation of achieved research score }}{\text { Accumulation of ideal score }} \times 100 \%$}

\subsection{Tabulate data}

Tabulating data is an activity to create tables containing data that has been coded according to the required analysis. So, at this stage the researcher will enter the data that has been processed and coded into the tables.

\subsection{Finding Results}

After calculating the answer scores from the respondents expressed in the form of percentages as above, then they are categorized according to the percentage table in the interval class. The next step is to calculate the final score, which will then be expressed in words to be described so that it is easy to read and understand.

After the results have been found, the next step is to describe the results, which are still in the form of numbers and then converted into words for easy understanding. In this case, the description will relate to a survey of cognitive dimensions in community response to the free vaccination programs in suppressing the spread of COVID-19 in Sidoarjo Regency based on data from respondents' answers that have been processed previously.

\section{RESULTS AND DISCUSSION}

\subsection{Characteristics of Respondents}

In this scientific article based on empirical research, the authors classify the characteristics of respondents based on age, education level, type of work, and vaccination status. Regarding the age range of respondents, as many as 93 percent of respondents are aged 18 to 64 years. Then followed by 3 percent of respondents aged 12 to 17 years, and 4 percent of respondents aged 65 years and over. Hurlock revealed that the older they are, the level of maturity and strength of a person would be more mature in thinking and working (Naibaho, 2016) [10]. Thus, the more mature the respondent's age, the more accurate information can be provided in this study.

Koentjoroningrat (1997) [11] states that education is the ability to absorb knowledge. The higher the level of education, the easier it is for a person to absorb knowledge. In this study, 39 percent of respondents had a bachelor's degree, then 36 percent of respondents with a senior high school education/equivalent, and 16 percent of respondents had postgraduate education. Furthermore, the last three levels of education are as much as 6 percent of which have graduated from a diploma, then 2 percent have just finished junior high school/equivalent, and only 1 percent have not completed school.

This shows that respondents can understand the questions asked by the research team in collecting research data. So that the data obtained is accurate. The respondents' occupations are 40 students, 19 private employees, 18 state civil servants, 23 percent are in other sectors/not working.

In addition, the last respondent's characteristics are related to the status of whether or not the respondent has received the COVID-19 vaccination. Most of the respondents, when the team conducted data collection, as many as 82 percent had received the first or second dose of vaccine injection. At the same time, the remaining 18 percent have not received any vaccine injections at all.

\subsection{Response Level}

Before discussing the community's response, first, understand what the response is. The response comes from the word response, which means a reply or response (reaction). The response is a psychological term used to describe responses to stimuli received by the five senses. The things that support and underlie the size of response are attitudes, perceptions and participation. A person's attitude precedes the response in the process because attitude is a person's tendency 
or willingness to behave when faced with a particular stimulus. In general, it can be said that there are three factors that influence a person's response, namely:

\subsubsection{The person concerned who sees}

The person concerned who sees and tries to give an interpretation of what he sees is influenced by his attitudes, motives, interests and expectations.

\subsubsection{The target of the response}

In the form of people, objects, or events. The characteristics of the mark usually affect the reaction of the viewer. In other words, the movement, sound, size, actions, and other characteristics of the response target also determine the way people view it.

\subsubsection{Situational factors}

The response can be seen contextually, which means in which situation the answer arises gets attention. The problem is a factor that plays a role in the formation of response of a person.

The response is essentially a response behavior or an attitude that becomes behavior back, which is also a process of organizing stimuli in which proximal stimuli are arranged in such a way that there is a phenomenal representation of these proximal stimuli. The response in the process is preceded by a person's attitude because attitude is a person's tendency or willingness to behave when faced with a certain stimulus. So attitude determines whether someone responds or does not respond to something.

Table 2. Distribution of Response Score

\begin{tabular}{|l|l|l|r|r|}
\hline \multirow{2}{*}{ Variable } & \multirow{2}{*}{ Dimension } & \multirow{2}{*}{ Indicator } & \multicolumn{2}{|c|}{ Score } \\
\cline { 3 - 5 } & & & $\mathrm{f}$ & $\%$ \\
\hline Response & Cognitive & Knowledge & 1.555 & 62.65 \\
\cline { 3 - 5 } & & Experience & 927 & 37.35 \\
\hline Total & & 2.482 & 100 \\
\hline
\end{tabular}

Source: Research Results, 2021 (processed data)

The response score obtained from the research results is 2,482 , as shown in table 1 , which is distributed according to the indicators.

\subsection{Cognitive Dimension}

The cognitive dimension is a dimension urgent and fundamental to capturing a picture of how good or bad the public response is. Sarlito (1995) cites the opinion of Jones and David, which states that the cognitive dimension studies a lot about how to understand oneself and the environment, as well as how to interact with the environment (Fuadah, 2011) [12].

Table 3. Cognitive Dimension Response Category

\begin{tabular}{|l|c|c|c|}
\hline \multirow{2}{*}{ Response Category } & \multirow{2}{*}{ Overall Score } & \multicolumn{2}{|c|}{ Total } \\
\cline { 3 - 4 } & & $\mathrm{f}$ & $\%$ \\
\hline Good & 2.482 & 23 & 23 \\
Enough & 62 & 62 \\
Bad & & 15 & 15 \\
\hline
\end{tabular}

Source: Research Results, 2021 (processed data)

Based on table 3 , it is found that the overall community response to the free vaccination program is sufficient. Where most of the respondents gave an adequate and good rating, namely 85 percent. This shows that the free vaccination program is still considered good by the community, even though there is 15 percent of the community who have bad or bad views.

\subsubsection{Indicators of Knowledge}

A person's response to an object, event and interaction with others cannot be separated from the perception he has as Liliweri (2015) [13] reveals that the response is influenced by perception where perception is always based on experience. So a common thread can be drawn that this knowledge indicator becomes a keychain in monitoring community responses and has strong relevance to the next indicator, namely the experience indicator.

Table 4. Knowledge Indicator Response Category

\begin{tabular}{|l|c|c|c|}
\hline \multirow{2}{*}{ Response Category } & \multirow{2}{*}{ Overall Score } & \multicolumn{2}{|c|}{ Total } \\
\cline { 3 - 4 } & & $\mathrm{f}$ & $\%$ \\
\hline Good & & 24 & 24 \\
Enough & 1.555 & 65 & 65 \\
Bad & & 11 & 11 \\
\hline
\end{tabular}

Source: Research Results, 2021 (processed data)

Based on table 4, it is found that the overall knowledge indicator is quite good, where there is 89 percent of respondents choosing enough and reasonable. This shows that 
free vaccination is considered a pretty good program by respondents, although there is a small percentage (11 percent) of respondents who do not yet have or meet this knowledge indicator.

\subsubsection{Experience Indicators}

An effective program will provide a good experience for the community. Liliweri (2015) [13] revealed that the knowledge possessed by a person advances the hope of accepting or rejecting a message according to his understanding. So it can be said that the experience indicator is one of the leading indicators because its impact is very striking and imprinted on the human cognitive dimension.

Table 5. Response Category Experience Indicators

\begin{tabular}{|l|c|l|l|}
\hline \multirow{2}{*}{ Response Category } & \multirow{2}{*}{ Overall Score } & \multicolumn{2}{|c|}{ Total } \\
\cline { 3 - 4 } & & $\mathrm{f}$ & \multicolumn{1}{c|}{$\%$} \\
\hline Good & & 36 & 36 \\
Enough & 927 & 55 & 55 \\
Bad & & 9 & 9 \\
\hline
\end{tabular}

Source: Research Results, 2021 (processed data)

Based on table 5, it is found that overall the experience indicators are quite good. That is, as many as 91 percent of respondents chose enough and good. This data shows that the respondent's experience with the government's free COVID-19 vaccination program is quite good.

\subsection{The Distribution of Responses}

The distribution of positive public responses to Susenas activities, when viewed by gender, may differ. Some research revealed that the psychological quality of men is different from that of women.

Table 6. Distribution of Response Frequency by Gender and Response Category

\begin{tabular}{|c|c|c|c|c|}
\hline \multirow[t]{2}{*}{ Gender } & \multirow{2}{*}{$\begin{array}{l}\text { Variable/ } \\
\text { Dimension/ } \\
\text { Indicator }\end{array}$} & \multicolumn{3}{|c|}{$\begin{array}{l}\text { Respond } \\
\text { Category }\end{array}$} \\
\hline & & G & $\mathrm{E}$ & B \\
\hline \multirow{2}{*}{ Man } & Response & 11 & 26 & 3 \\
\hline & Cognitive & 11 & 26 & 3 \\
\hline \multirow{2}{*}{ Woman } & Response & 13 & 38 & 9 \\
\hline & Cognitive & 13 & 38 & 9 \\
\hline
\end{tabular}

Source: Research Results, 2021 (data processed)

Men with analytical skills will view the government's free COVID-19 vaccination program as a helpful activity and need to be supported so that they respond to the good one. In Table 5, it can be seen that the male population gave a sufficient and reasonable response to the free COVID-19 vaccination program by the government.

Women with the characteristics and responsibilities they carry tend to be more aware of matters relating to the safety of their families, primarily if these activities are related to the health of their families. This can be seen from the unfavorable response, which is higher than men. Although overall female respondents gave a fairly good response.

The role of women as housewives who regulate the fulfillment of household needs and know what is needed encourages them to be more aware of the importance of providing factual data.

Table 7. Distribution of Age Response Frequency and Response Categories

\begin{tabular}{|c|l|l|l|l|}
\hline \multirow{2}{*}{ Age } & \multicolumn{1}{|c|}{$\begin{array}{c}\text { Variable/ } \\
\text { Dimension/ } \\
\text { Indicator }\end{array}$} & \multicolumn{2}{|c|}{ Respond Category } \\
\cline { 3 - 5 } & \multicolumn{1}{|c|}{$\mathrm{G}$} & $\mathrm{E}$ & $\mathrm{B}$ \\
\hline \multirow{2}{*}{$12-17$} & Response & 1 & 2 & 0 \\
\cline { 2 - 5 } & Cognitive & 1 & 2 & 0 \\
\hline \multirow{2}{*}{$18-64$} & Response & 20 & 58 & 15 \\
\cline { 2 - 5 } & Cognitive & 20 & 58 & 15 \\
\hline \multirow{2}{*}{$65+$} & Response & 0 & 3 & 1 \\
\cline { 2 - 5 } & Cognitive & 0 & 3 & 1 \\
\hline
\end{tabular}

Source: Research Results, 2021 (data processed)

In Table 7 shows that the majority of respondents are in the age group of 18 to 64 years. This age group is an age group that is vulnerable to being exposed to COVID-19 because they do a lot of activities, both to earn a living and other activities. In this age group, respondents' answers can provide an accurate response to this study. Respondents aged 18 to 64 years thought the government's free COVID-19 vaccination program was quite good. Although some think it's not good.

Furthermore, the second largest age group of respondents in this study was over 65 years of age. This age group gave a sufficient response to the implementation of the free COVID19 vaccination program by the government. Of the total four respondents in this age group, one person thought the government's free COVID-19 vaccination program was not good. But overall, this program is considered sufficient.

The last age group is 12 to 17 years old. This age group responded quite well to the government's implementation of the free COVID-19 vaccination program. 


\section{CONCLUSION}

Based on the analysis and analysis of the data on the results and discussion of the research, we can see that the public's response to the free vaccination program on the cognitive dimension, especially the knowledge indicator, shows quite positive to positive results. Where the results are quite positive, it can be seen in the majority of responses (65 percent) and at the level of positive effects as many as 24 percent.

Almost uniform with the knowledge indicator, the experience indicator also displays a better response, where as many as 36 percent stated positive results and 55 percent at a fairly good/positive level. Even so, it turns out that there is still a minority (9 percent) who still doubt or even negatively stigmatize the free vaccination program.

So in general, it can be concluded that most of the community's responses from the cognitive dimension as a whole and individually to the Free Vaccination Program in Sidoarjo Regency are pretty positive (62 percent) and positive (23 percent) with a total of 85 percent. Even so, the remaining 15 percent who said they were negative need to be explored and studied more deeply in the future.

Therefore, the Regional Government of Sidoarjo Regency needs to further promote socialization to the public about the importance and benefits of the free vaccination program. With this, it is hoped that it will eliminate doubts and disinformation related to the free vaccination program.

\section{REFERENCES}

[1] CNBC Indonesia, "RI Keeps Record, New Covid-19 Cases Reach 54,000," www.cnbcindonesia.com, 2021. [Online]. Available: https://www.cnbcindonesia.com/news/202107142306424-260960/ri-cetak-rekor-terus-kasus-baru-covid-19tembus-54000/2. [Accessed: 09-Winter-2021].

[2] D. Permatasari, "Covid-19 policy from PSBB to fourlevel PPKM," kompaspedia.kompas.id, 2021. [Online]. Available:

https://kompaspedia.kompas.id/baca/infografik/kronologi /kebijakan-covid-19-dari-psbb-hingga-ppkm-empatlevel. [Accessed: 09-Autumn-2021].

[3] Decree of the Minister of Health of the Republic of Indonesia Number Hk.01.07/Menkes/382/2020 concerning Health Protocols for the Community in Public Places and Facilities in the context of Prevention and Control of Corona Virus Disease 2019 (Covid-19)

[4] Ministry of Health, "Spread of COVID-19 Healed Cases in Indonesia from March 2020 to March 2021," 2021.

[5] Sidoarjo Regency Communication and Information Office, "Incidence Rate in Sidoarjo Regency," 2021.

[6] V. Ramachandran, S. Esaki M, V. Vijayakumar, and T. Sadras Panchatcharam, "Is herd immunity against SARSCoV-2 a silver lining?," Front. Immunol., vol. 11, p. 586781, 2020

[7] Presidential Regulation Number 99 of 2020 concerning Vaccine Procurement and Vaccination Implementation in the context of Combating the Corona Virus Disease 2019 (Covid-19) Pandemic.

[8] Sugiyono, Statistika untuk Penelitian. Bandung: Alfabeta, 2012.

[9] M. M. Ariola, Principles and methods of research. Manila, Filipina: Rex Book Store Inc, 2006.

[10] M. Naibaho, "Community Response to the Communication Message of the National SocioEconomic Survey at BPS Pematangsiantar City," J. SIMBOLIKA Res. Learn. Commun. Study, vol. 2, no. 1, 2016.

[11] S. Koentjaraningrat, "Society Research Methode". Jakarta: PT. Gramedia, 1997.

[12] A. F. Fuadah, "Student Response To Gender Sensitivity In Course Materials In Department Of Communication And Broadcasting Islamic Uin Sharif Hidayatullah Jakarta," Syarif Hidayatullah State Islamic University, Jakarta, 2011

[13] A. Liliweri, Inter-Personal Communication. Jakarta: Prenadamedia Group, 2015. 